\title{
Socio-Economic Analysis of Ginger Production in Surkhet District of Nepal
}

\author{
Jyoti Neupane $^{1 *}$, Soni Ghimire ${ }^{1}$, Devendra Prasad Chalise ${ }^{1}$ and Durga Devkota ${ }^{2}$ \\ ${ }^{1}$ Bachelor Graduate, Agriculture and Forestry University, Nepal \\ ${ }^{2}$ Professor, Center for Development Studies and Rural Sociology, Nepal \\ *Corresponding Author: Jyoti Neupane, Bachelor Graduate, Agriculture and Forestry University, Nepal.
}

Received: September 12, 2019; Published: October 15, 2019

\begin{abstract}
The survey research entitled 'Socioeconomic analysis of ginger production in surkhet district' was conducted during March 2019 to May 2019. The Gurwakot, Bheriganga and Awalching was selected purposefully and sample HHs was selected randomly. A total of $30 \mathrm{HHs}$ were selected as sample from Bheriganga and each 25 from Gurwakot and Awalching. The data was collected through household survey (80HHs), 3 focus group discussion (FGD) and key informant survey (KII). In the sampled HHs, the percentage of male and female respondents was equal. Unavailability of enough and quality seed, Rhizome rot, Rhizome fly and trader's dominance in price determination has limited the success of ginger cultivation in the area. Out of the total landholding of 881 ropani, $46.31 \%$ was used in ginger cultivation. The average landholding of the respondents was 12.31 ropani and an average of 2.31 ropani land was used by them in ginger cultivation. Majority of the farmers used seed rhizome reserved from own production for planting materials (66.25\%) in the next cycle. All the respondents used organic manure as source of nutrients. Most of the farmers practiced family labour and exchanged labour as source of labour for ginger cultivation. Only $8.75 \%$ of the respondents sold their product directly to the consumers, $38.75 \%$ sold their product to the Organic Mountain Flavour industry. $48.8 \%$ respondents got price information from collectors and $42.5 \%$ respondents were unsatisfied with price they received for their product, only $16.25 \%$ were satisfied with price. Most of the farmers did not perform Bruni extraction. The total cost of production was found to be NRs. 3,48,500 per hectare out of which cost of seed and human labour found to contribute major part i.e. NRs.1,69,860 (48.74\%) and NRs. 1,25,460 (36.0\%) respectively. Benefit cost analysis revealed that the $\mathrm{B} / \mathrm{C}$ ratio was 1.88 on average. Thus, the ginger farming could be preferable and profitable, that could raise socioeconomic status of farmers of surkhet district of Nepal.
\end{abstract}

Keywords: Socioeconomic; Ginger; Surkhet; Survey; Analysis

\section{Introduction}

According to the National Census 2068, number of households in Surkhet district is 72863 and $59.46 \%$ of total population is involved in Agriculture. The total arable land in the district is 55200 ha of which $20.96 \%$ is suitable for cultivation and $15 \%$ is only cultivated [1]. The major agriculture commodities of the district are wheat, maize, paddy, ginger, turmeric, and honey, seasonal and offseason vegetable of which ginger is cultivated in the area of 512 ha with the production 8192 ton and productivity of 16 ton/ha (MoAD, 2074/75). Ginger (Gingiber officinale Rose.) is an important and promising High Value Crops (HVCs) grown especially in mid hills of Nepal which has a large production and export potential [2]. Ginger is shade loving flowering plant. It grows in the marginal and sub-marginal lands of midhills between the altitudes of 600-1600 and optimum temperature for ginger cultivation is 20-30-degree $\mathrm{C}$ [3]. The farmers are attracted towards ginger farming due to comparative advantage and existence of favorable climatic condition of Nepal [4]. Ginger is used in many forms and with different ingredient. It can be used raw or in dried and powdered form. Ginger is used in making sauces, pickles, squash, beverages and candy [5]. Nepal falls on fourth rank in terms of ginger production after India,
China and Indonesia. Also, Nepal is the world's fourth largest exporter. Nepalese exports were of approximately US\$ Six Million in the fiscal year 2015/16 [6]. Ginger is one of the 12 priority export products of the Nepal Trade Integration Strategy (NTIS) defined by the Government of Nepal. Until 2020, this national strategy aims to increase the export price for Nepalese ginger via value addition in the country from 217 US\$/MT to 815 US\$/ MT. The diversification of export markets remains the biggest challenge for the Nepalese ginger sector [6]. In Nepal 23855ha area is under ginger cultivation and production of $263140 \mathrm{Mt}$ in 2072/7 [7] 3.40\% of the total ginger production is used as planting material, $40 \%$ is exported to foreign country and only $20 \%$ is used for home consumption and medicinal purpose within the country [8].

\section{Methodology}

Eighty ginger growers involved in cooperatives; group's member of the selected area were sampled for the study through simple random sampling. 30 sample were selected from Bheriganga Municipality, each 25 sample were selected from Gurwakot Rural Municipality and Awalching Rural Municipality. The farmers of selected site were the major sources of the primary data and data 
were collected through semi structured interview schedule applying face to face interview technique. Apart from this, information were obtained through observations, focus group discussion and key informant survey was also given due consideration. Secondary information was collected from various sources like: Annual report of Agriculture Knowledge Centre (AKC), Surkhet, Previous survey recommendations, Journals articles and publications, Central Bureau of Statistics (CBS), Publications of DDC, DOA, NARC, VDC, FNCCI, Surkhet profile, Newspaper articles etc.

\section{Data analysis}

Both primary and secondary information collected from field survey and other methods were coded, tabulated in computer and analysed by using Statistical Package of Social Science (SPSS) and Microsoft Excel. Different variables in this study were used on both quantitative and descriptive analysis.

\section{Result and Discussion}

Socio-economic characteristics of the respondent

From the study it was found that there were equal number of male 50 percent and female 50 percent respondent in the study area with $68.8 \%$ between the age group $30-50$ years, $16.2 \%$ less than 30 years and $15.0 \%$ more than 50 years. Based on their caste namely, Bhrahmin and Chhetri, Janjati and Dalit. Bhramin and Chhetri $67 \%$ were the dominant caste in the study area followed by Dalit $30 \%$ and Janjati $2.5 \%$. Majority of the family was found to prefer joint family $66.2 \%$ followed by Nuclear $31.2 \%$. Only $2.5 \%$ of extended family were found. The average family size of the study area was found to be 6.86. Overall mean independent population size was found to be higher than that of mean dependent population size, which means more working population than non-working populations. The average family members working in ginger field were about 5.20 which shows that ginger has provided an opportunity of employment to many households.

\begin{tabular}{|l|c|c|c|c|}
\hline & Minimum & Maximum & Mean & St.Deviation \\
\hline $\begin{array}{l}\text { Number of family } \\
\text { members }\end{array}$ & 2 & 14 & 6.86 & 2.48 \\
\hline $\begin{array}{l}\text { Number of } \\
\text { dependent } \\
\text { members in family }\end{array}$ & 0 & 8 & 2.29 & 1.66 \\
\hline $\begin{array}{l}\text { Number of } \\
\text { independent } \\
\text { members in family }\end{array}$ & 1 & 9 & 4.57 & 2.03 \\
\hline $\begin{array}{l}\text { Number of family } \\
\text { member involved } \\
\text { in ginger farming }\end{array}$ & 1 & 11 & 5.20 & 1.92 \\
\hline
\end{tabular}

Table 1: Distribution of respondents based on family size.

With the classification of education into four categories majority of the respondents were informally educated 26 followed by under SLC. Only 16 of them were under SLC followed by illiterate 14 . Study revealed that population that were solely involved in Agriculture was found to be $31.2 \%$ while remaining other were involved in agriculture plus other work like business, service, abroad (Table 2).

\begin{tabular}{|l|c|c|}
\hline \multicolumn{1}{|c|}{ Primary Occupation } & Frequency & Percent \\
\hline Agriculture & 25 & 31.2 \\
\hline Agriculture and Business & 8 & 10.0 \\
\hline Agriculture and Service & 26 & 32.5 \\
\hline Agriculture and Abroad & 18 & 22.5 \\
\hline Agriculture, Service and Abroad & 3 & 3.8 \\
\hline Total & 80 & 100.0 \\
\hline
\end{tabular}

Table 2: Distribution of respondents based on primary occupation.

Average LSU of the sampled household were 7.13 (6.23 St. Deviation) and minimum and maximum LSU among sampled household were found to be 3 and 47 respectively. Nepalese follow the integrated farming system. Agriculture and livestock are major two component of Nepalese agriculture which help to sustain livelihood of most of the Nepalese people. In Nepalese agriculture, livestock contributes $25.6 \%$ in the gross domestic product of Nepal [9]. Ginger is a heavy feeder crop and requires on an average $1000-1200$ $\mathrm{kg}$ of manure per ropani. As the sampled household were practicing organic ginger farming from ancient time livestock contribute most of the organic by-product to the ginger field from manure to urine.

Information on Membership in social organisation shows respondents mobility. Individual involved in social organisation got chance to get participated in various program like trainings, workshop, farmers visit etc. People who participate in such program get more idea about technology, opportunity, skills and knowledge. Out of the 80 respondents 58.8\% were involved in Farmer's group, 32.5 involved in cooperatives and remaining $7 \%$ were membership in other social organisations.

The study showed that total land of the farmers used for agriculture purpose ranged from 3 to 39 ropani with average land holding of 12.31 in the study area. Similarly, mean land under ginger cultivation was found 2.31 ropani ranging from 1.00 to 10 ropani with share of land under ginger cultivation in total being 46.31 .

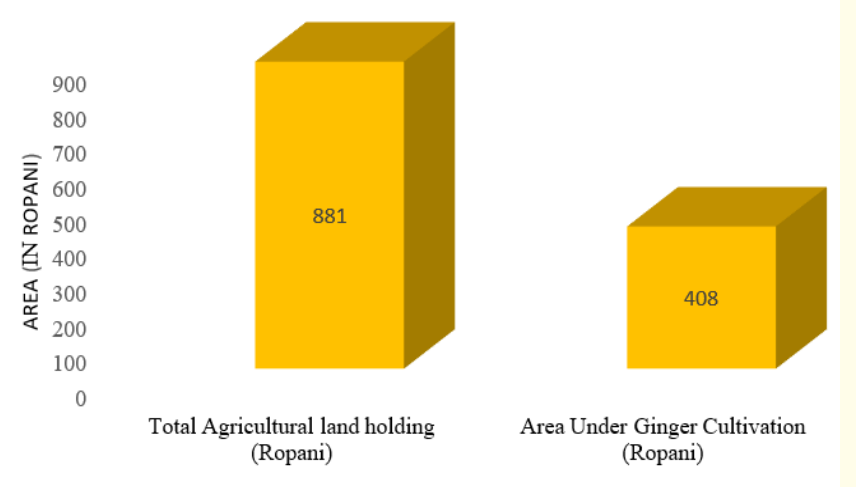

Figure 1: Total agricultural land and total land under ginger cultivation in study area. 
Farming experience is an important variable in determining the quality and quantity of production technologies. The study revealed that $42.5 \%$ of farmers have been cultivating ginger from more than 20 years followed by $10-15$ years (17.5\%), 5-10 years (16.2\%), 1-5 years $(12.5 \%)$ and $15-20$ years (11.2). It shows that ginger cultivation in the study area was taken as major farming practices and this practice is transferring from one generation to another. Most of the farmers producing ginger were small farmers for whom it is a main source of cash income. From the study it was found that percentage share of ginger to total income was $4 \%$ to $61 \%$ with mean $24.04 \%$ (15.08\% St. Deviation). The study has revealed that majority of respondents $(35.0 \%)$ used labour in co-operation/exchange and minimum $13.75 \%$ of respondents used both family and hired labour. Those who used only hired labour was $20 \%$.

From the analysis, it was found that majority of respondents $(66.25 \%)$ were using seeds reserved from their own production. Only $6.25 \%$ of farmers bought seeds from the market (Table 3 ).

\begin{tabular}{|l|c|c|}
\hline \multicolumn{1}{|c|}{ Source of seed } & Frequency & Percent \\
\hline Reserve from own production & 53 & 66.25 \\
\hline Fellow farmer/Neighbours & 10 & 12.5 \\
\hline Cooperatives/Farmer group & 12 & 15.0 \\
\hline Market & 5 & 6.25 \\
\hline Total & 80 & 100.0 \\
\hline
\end{tabular}

Table 3: Distribution of respondents based on sources of seed.

In the study area $41.25 \%$ of respondents sold their product to co-operatives/ farmers. Similarly, significant number of respondents sold their ginger to organic mountain flavour (Industry) $(38.75 \%)$ followed by respondents who sold the product directly to the consumer $(8.75 \%)$ without involvement of any middleman and $11.25 \%$ respondents sold their product to whole seller. 42.5 percent of the people were unsatisfied with the price that they receive after selling ginger whereas only 13.75 percent of them were satisfied. Market price of ginger in Nepal is dependent on ginger production and pricing in India and the price that farmers receive for their product has great implications for poverty alleviation and to uplift socio-economic status of farmers.

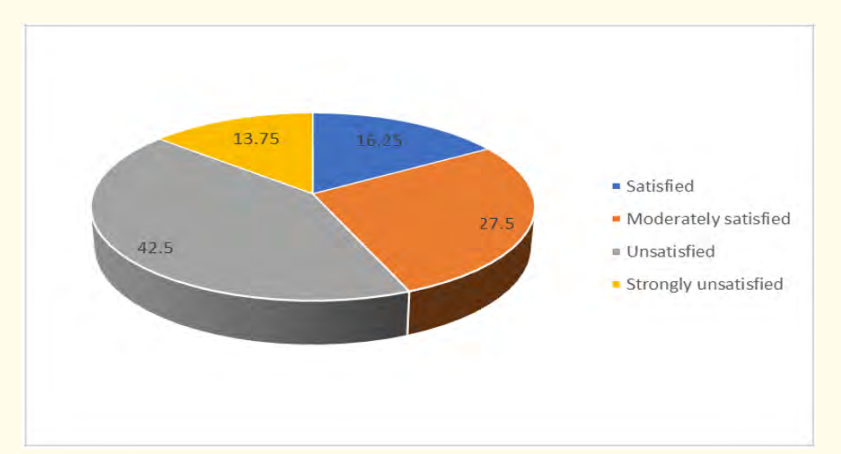

Figure 2: Distribution of respondents based on price satisfaction.
Sources of price information were classified into four categories based on their response namely, (i) Neighbours, (ii) Market Analysis, (iii) Collectors, (iv) Middleman. The study revealed that majority of respondents (48.8) get to know price from collectors (Table 4).

\begin{tabular}{|l|c|c|}
\hline \multicolumn{1}{|c|}{ Sources } & Frequency & Percent \\
\hline Neighbours & 12 & 15.0 \\
\hline Market analysis & 27 & 33.8 \\
\hline Collectors & 39 & 48.8 \\
\hline Middleman & 2 & 2.5 \\
\hline Total & 80 & 100.0 \\
\hline
\end{tabular}

Table 4: Distribution of respondents based on sources of price information.

Only small number i.e.7 out of total farmers practised Bruni extraction. Bruni extraction is process of extraction of mother rhizome leaving the sprouted piece of rhizome in the soil during off season (May or June). This practice gives proper space to the developing rhizome and although the quality of rhizome is inferior farmers get income due to the off-season price advantage [10]. But due to lack of knowledge and traditional way of farming nature, farmers of surkhet district were unaware of advantage of Bruni extraction. Remaining 73\%of farmers didn't practice bruni extraction. Cropping system in the study area was classified into two categories namely (i) Mixed cropping and (ii) Sole Cropping. Maize, Legumes, Banana etc were mixed with ginger in order to provide shade for the crop. The study shows that majority (92.5\%) of farmers practiced mixed cropping system while $7.5 \%$ of them practiced sole cropping. In the study area Most respondents (76.2\%) follow crop rotation while $23.8 \%$ of population cultivated without crop rotation, Ginger absorbs the large amount of nutrients from the soil. So, ginger shouldn't be cultivated in the same land continuously. Crop rotation also helps to reduce rhizome rot disease. Among the surveyed household, $65.0 \%$ of respondents applied pit storage system followed by Bhakari system (28.8\%) and In-situ storage (6.2\%).

Gender participation on household and agricultural decision Gender participation on $\mathrm{HH}$ decision

Study showed that most of the household decision were taken by male (Table 5) in the study area. The Low participation of female in decision making process may be due to male dominated society, low educational status among the female.

\begin{tabular}{|l|c|c|c|c|}
\hline Variables & Male & Female & Mutual & Total \\
\hline Family Head & $59(73.8)$ & $21(26.2)$ & ------- & $80(100.0)$ \\
\hline HH Expense & $45(56.2)$ & $20(25.0)$ & $15(18.8)$ & $80(100.0)$ \\
\hline $\begin{array}{l}\text { Overall HH } \\
\text { Management }\end{array}$ & $44(55.0)$ & $19(23.8)$ & $17(21.2)$ & $80(100.0)$ \\
\hline
\end{tabular}

Table 5: Distribution of respondents based on gender participation on $\mathrm{HH}$ decision. 


\section{Gender participation on agriculture decision}

There was no distinct difference between participation of gender in Labour Management for ginger production but male has greater influence than female in ginger production, marketing decision and loan taking. Its shows that female have less access to financial activities. Also, there was nearly equal participation of gender in training

\begin{tabular}{|l|c|c|c|c|}
\hline \multicolumn{1}{|c|}{ Variables } & Male & Female & Mutual & Total \\
\hline Labour Management & $\begin{array}{c}32 \\
(40.0)\end{array}$ & $\begin{array}{c}34 \\
(42.5)\end{array}$ & $\begin{array}{c}14 \\
(17.5)\end{array}$ & $\begin{array}{c}80 \\
(100.0)\end{array}$ \\
\hline $\begin{array}{l}\text { Ginger production and } \\
\text { marketing }\end{array}$ & $\begin{array}{c}45 \\
(56.2)\end{array}$ & $\begin{array}{c}22 \\
(27.5)\end{array}$ & $\begin{array}{c}13 \\
(16.2)\end{array}$ & $\begin{array}{c}80 \\
(100.0)\end{array}$ \\
\hline Loan Taking & $\begin{array}{c}56 \\
(70.0)\end{array}$ & $\begin{array}{c}17 \\
(21.2)\end{array}$ & $7(8.8)$ & $\begin{array}{c}80 \\
(100.0)\end{array}$ \\
\hline $\begin{array}{l}\text { Participation on } \\
\text { Training }\end{array}$ & $\begin{array}{c}31 \\
(38.2)\end{array}$ & $\begin{array}{c}25 \\
(31.2)\end{array}$ & $\begin{array}{c}24 \\
(30.0)\end{array}$ & $\begin{array}{c}80 \\
(100.0)\end{array}$ \\
\hline
\end{tabular}

Table 6: Distribution of respondents based on gender participation in agricultural decision.

Access to Extension Service and Training Status In the study area

Government agencies, NGO's and co-operatives were working as service providers in the study area. The percentage of respondents who were benefitted from service providers was higher (78.8\%) but there were still significant numbers of respondents behind their reach. In the study area, only $52.5 \%$ have taken trainings for ginger production (Table 7).

\begin{tabular}{|l|c|c|}
\hline & Yes & No \\
\hline Interaction with extension officer & $63(78.8)$ & $17(21.2)$ \\
\hline Service Taken & $46(57.5)$ & $34(42.5)$ \\
\hline Training & $42(52.5)$ & $38(47.5)$ \\
\hline
\end{tabular}

Table 7: Distribution of respondents based on access to extension service and training status.

Ranking of problems

Ranking of major problems of ginger production

The value obtained from the ranking scale revealed that incidence of disease and pest is most severe problems having highest index value i.e.0.71 and Mulching materials less severe problems having lowest index value i.e.0.50.

\begin{tabular}{|l|c|c|}
\hline \multicolumn{1}{|c|}{ Major Production Problem } & Index Value & Rank \\
\hline Lack of Sufficient and quality seed & 0.62 & III \\
\hline Lack of Technical and financial support & 0.63 & II \\
\hline Insufficient labour & 0.52 & IV \\
\hline Incident of disease and pest & 0.71 & I \\
\hline Unavailability of mulching materials & 0.50 & V \\
\hline
\end{tabular}

Table a: Ranking of major problems of ginger production in study area.
Problems related to marketing of the ginger

The value obtained from index value revealed that Trader dominance in price determination is the most severe problem with index value 0.69 and Unavailability of road is the least severe problem with index value 0.38 (Table 8).

\begin{tabular}{|l|c|c|}
\hline \multicolumn{1}{|c|}{ Major Marketing Problem } & Index Value & Rank \\
\hline Insufficient price to cover & 0.62 & III \\
\hline Lack of road access & 0.38 & V \\
\hline $\begin{array}{l}\text { Trader dominance in price determina- } \\
\text { tion }\end{array}$ & 0.69 & I \\
\hline No formal agreement with traders & 0.68 & II \\
\hline Lack of storage & 0.60 & IV \\
\hline
\end{tabular}

Table 8: Ranking of major ginger marketing problems in study area.

\section{Major disease of the ginger}

Average ranking among the disease of ginger showed Rhizome rot as major disease ranking first ( $\mathrm{I}=0.78)$. Similarly, Leaf spot $(I=0.69)$ ranked as second followed by Storage mould ( $I=0.59)$ holding third rank (Table 9).

\begin{tabular}{|l|c|c|c|c|c|c|}
\hline \multirow{2}{*}{ Problems } & \multicolumn{3}{|c|}{ Score } & \multirow{2}{*}{ Weightage } & $\begin{array}{l}\text { Index } \\
\text { value }\end{array}$ & Rank \\
\cline { 2 - 6 } & $\mathbf{1}$ & $\mathbf{0 . 6 6}$ & $\mathbf{0 . 3 3}$ & & & \\
\hline $\begin{array}{l}\text { Rhizome } \\
\text { rot }\end{array}$ & 40 & 28 & 12 & 62.44 & 0.78 & I \\
\hline $\begin{array}{l}\text { Storage } \\
\text { mould }\end{array}$ & 23 & 18 & 39 & 47.75 & 0.59 & III \\
\hline Leaf Spot & 33 & 22 & 25 & 55.77 & 0.69 & II \\
\hline
\end{tabular}

Table 9: Ranking of major disease of ginger in study area.

\section{Major insects of ginger}

Average ranking among the insects of ginger showed Rhizome fly as major insect ranking first ( $\mathrm{I}=0.77)$. Similarly, white grub ( $\mathrm{I}=0.70)$ was ranked as second followed by Red ant ( $\mathrm{I}=0.64$ ) holding third rank (Table 10).

\begin{tabular}{|l|c|c|c|c|c|c|}
\hline \multirow{2}{*}{ Problems } & \multicolumn{3}{|c|}{ Scores } & \multirow{2}{*}{$\begin{array}{c}\text { Total } \\
\text { weightage }\end{array}$} & $\begin{array}{c}\text { Index } \\
\text { value }\end{array}$ & Ranking \\
\cline { 2 - 6 } & $\mathbf{1}$ & $\mathbf{0 . 6 6}$ & $\mathbf{0 . 3 3}$ & & \\
\hline Rhizome fly & 43 & 21 & 16 & 62.14 & 0.77 & I \\
\hline White grub & 37 & 26 & 17 & 56.47 & 0.70 & II \\
\hline Red ant & 29 & 17 & 34 & 51.44 & 0.64 & III \\
\hline
\end{tabular}

Table 10: Ranking of major insect of ginger in study area.

\section{Economics of ginger production}

Cost of production

Ginger cultivation in Nepal is done mostly by traditional methods. The major components in production of ginger include Input costs, labour cost and land preparation cost [11]. The cost of machineries (plough, spade, sickle etc) for cultivation is very nominal. Similarly, home-made organic manure (Farmyard manure and Compost) is mostly used rather than chemical fertilizers. The use of improved seed is also very rare and most of farmers are using lo- 
cally available seed varieties. In ginger cultivation, the major part of the cost goes in seed with $48.74 \%$ of the total production cost, but in the study by $[12,13]$ was $46.0 \%$ and $61.25 \%$ respectively. The difference in percentage may be due to different price of seed rhizome and different seed rate in different location. Usually, seed are being produced by farmers themselves and keep for next season plantation. Farmers keep 20 to $25 \%$ of their production as a purpose of seed. New growers purchase seeds from neighbouring farmers or from local market. The cost of seed is higher than the fresh ginger. Manure incur $9.45 \%$ of total cost of production. They use only organic manure and ginger produce in that area is purely organic.

Ginger farming in Nepal is very labour intensive. Hence, the share of labour cost in total cost of production is around $36.0 \%$ (Table 11). Labour is mainly used for land preparation, ploughing, plantation, FYM application, mulch collection and application, weeding, harvesting and post-harvest handling activities. During ploughing, farmers usually use bullocks. If the farmers do not have own bullocks or have shortage of it, they usually hire bullocks from others. The cost of a pair of bullocks per day is normally Rs. 1000 . Mulch collection is done from surrounding area, farm or nearby forest and the cost mainly includes labour cost of transporting and laying it in field. In the post-harvest handling, the rhizomes are separated from the stem and soil removed from rhizomes. There is absence of washing and grading practice at farmers' level. In most of the cases, the family members are involved in providing the labour. Use of outside labour is mostly done by farmers with medium and big farms. Normally, the service charge of labour per day ranges from Rs. 450 to 600 depending upon the area. Due to aggressive seasonal migration of labourers to overseas work, it is becoming scarce day by day [14-34].

\begin{tabular}{|l|c|c|c|}
\hline S. N & Description & $\begin{array}{c}\text { Average cost of } \\
\text { production } \\
\text { (Rs/ha) }\end{array}$ & $\begin{array}{c}\text { Contribution } \\
\text { of total average } \\
\text { cost (\%) }\end{array}$ \\
\hline 1. & Seed & 169860 & 48.74 \\
\hline 2. & Labour & 125460 & 36.0 \\
\hline 3. & Manure & 32940 & 9.45 \\
\hline 4. & Others & 20240 & 5.8 \\
\hline 5. & $\begin{array}{c}\text { Total Average } \\
\text { production cost }\end{array}$ & 348500 & 100.0 \\
\hline
\end{tabular}

Table 11: Cost of production of ginger per ropani in the study area.

\section{Return from ginger production}

The study showed that gross return and total cost were estimated about NRs.6,55,600 per ha and NRs.3,48,500 per ha respectively. Gross margin of ginger production was calculated at about NRs.3,07,100 per ha. The overall undiscounted benefit cost ratio considering total cost was 1.88 (Table 12). It indicates that the ginger production is profitable in the study area.

\begin{tabular}{|l|c|}
\hline \multicolumn{1}{|c|}{ Items } & Amount in NRs. \\
\hline Total Cost (NRs. /ha) & $3,48,500$ \\
\hline Gross Returns (NRs/ha) & $6,55,600$ \\
\hline Average per kg production cost & 29 \\
\hline Average per kg price & 50.50 \\
\hline Average per kg margin & 21.50 \\
\hline Benefit cost ratio & 1.88 \\
\hline
\end{tabular}

Table 12: Return from the ginger per ropani in the study area.

\section{SWOT analysis of ginger production}

From SWOT analysis through Focus group discussion FGD following strength, weakness, opportunity and threat were obtained for ginger production in the study area.

\begin{tabular}{|c|c|}
\hline & \\
\hline $\begin{array}{l}\text { - } \text { Climatic Suitability } \\
\text { - Access to the inputs, road } \\
\text { and market } \\
\text { - Higher return from ginger } \\
\text { compared to cereals } \\
\text { - Less perishable than other } \\
\text { commodities } \\
\text { - Possibility of inter-cropping } \\
\text { with maize, bean, and veg- } \\
\text { etables } \\
\text { - Crop rotation } \\
\text { - Easy and affordable pit } \\
\text { storage system } \\
\text { - Involvement of co-opera- } \\
\text { tives and farmer's group in } \\
\text { marketing } \\
\text { Opportunity for organic } \\
\text { production }\end{array}$ & $\begin{array}{l}\text { - } \begin{array}{l}\text { Non availability of } \\
\text { enough and quality } \\
\text { seeds }\end{array} \\
\text { - Lack of technical } \\
\text { knowhow } \\
\text { - } \begin{array}{l}\text { Poor knowledge on } \\
\text { value addition and } \\
\text { grading }\end{array} \\
\text { - Insufficient market } \\
\text { - Traders dominance in } \\
\text { price determination }\end{array}$ \\
\hline Opp & Threats \\
\hline $\begin{array}{ll}\text { - } & \text { High demand of ginger } \\
\text { - } & \text { Establishment of PMAMP } \\
\text { - } & \text { Relatively good price } \\
\text { available to farmers } \\
\text { - } & \text { Centrally located market } \\
\text { - } & \text { Establishment of Organic } \\
\text { Mountain Flavour (OMF) } \\
\text { Industry }\end{array}$ & 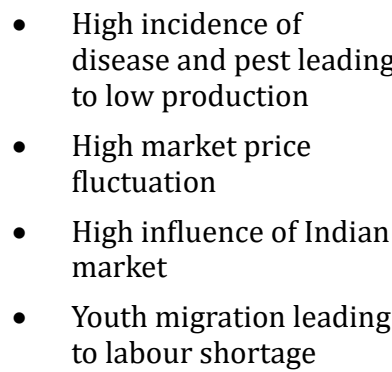 \\
\hline
\end{tabular}

Table b

\section{Conclusion}

From the study it can be concluded that average family size was larger than the national average. The major occupation of the sampled HHs in the study site was agriculture and ginger farming was usually preferred by the HHs of the study area however, income from others crop, livestock also contributes significantly. Ginger have significant contribution to raise the socio-economic status of the rural people, earn foreign currency and decrease environmental degradation. It can be cultivated in crop field, sloppy land and even 
in marginalized land. Labour required for the cultivation practices of ginger was relatively higher than that of labour required for another agricultural commodity. Benefit cost ratio indicates that the crop appears profitable in the selected area of Surkhet district. This crop contributes significantly to the household income thus can be better option for uplifting the socio-economic status of the farmers of study site. The export share of the commodity implies that it is highly export oriented cash crop commodity.

\section{Bibliography}

1. Zone. PMAMP: GInger/Turmeric. Zone Profile (2017).

2. ITC (2007)

3. H Rahman., et al. "Traditional practices of ginger cultivation in Northeast India". Indian Journal of Traditional knowledge (2009).

4. KC., et al. "Ginger and Turmeric Production: Improved Technology”. Kapurkot, Salyan: Kwality Printers (2012).

5. FAO. "Ginger: post production Management for Improved Market Access". (2002).

6. "Ginger sector in Nepal". n.d.

7. AICC (2074)

8. Poudel Rewati Raman. "Economic analysis of Ginger cultivation in selected locations of Palpa, Nepal". Azarian Journal of Agriculture (2016).

9. Adhikari, Buddhi prakash sharma. "Nepal Ginger Profile" (2016).

10. University, Texas A\&M. "Bruni Extraction”. (2015).

11. HVAP. "Value chain analysis of ginger subsector in Nepal" (2011).

12. USAID/NEPAL. VALUE CHAIN/ MARKET analysis of the GInger Sub-sector in Nepal (2011)

13. Timsina Kishna. "Economics of ginger production: A case study of makawanpur district, Nepal". Research gate (2011).

14. MoAD. n.d. (2015)

15. "A study on Ginger and Cardamom Marketing in Nepal". (n.d.).

16. Agriculture Sector Profile. Kathmandu: Government of Nepal (2016).

17. Baral H and Suwal P. "Feasibility study of drying units and marketing of cardamom in sankhuwasabha district". (1999).

18. GC Arun., et al. "Diagnostic study of Ginger Market Access for Eastern and Western region of Nepal”. Research Gate (2019).

19. https://www.mercycorps.org/nepal-ginger-farming. (n.d.).

20. https://www.webindia123.com/garden/herb_spi/ginger. htm. n.d.

21. ICAR. Research Hightlight. ICAR- Indian Institute of Spices Research (2017).
22. “Export potential Assessment in Nepal” (2007).

23. Joe Leech, MS. "11 proven Health Benefits of Ginger". Health line (2017).

24. Khanal Kapil. "Factors Affecting and Marketing Chain of Ginger in Salyan". International Journal of Applied Science and Biotechnology (2018).

25. Khanal Rajesh (2018).

26. MoAD 2014

27. "Statistical Information on Nepalese Agriculture". 2074/75.

28. Nair KP Prabhakaran. The Agronomy and Economy of Turmeric and Ginger (2013).

29. Pandey Swikriti., et al. "Value chain analysis of ginger in Sunsari districts of Nepal". Acta Scientific Agriculture (2019).

30. Pokhrel Chandra Prasad. "Assessment of plant diversity in homegardens of three ecological zones of Nepal". Ecoprint: An International Journal of Ecology (2016).

31. Pudasaini S. "The effect of Education in Agriculture: Evidence from Nepal”. American Journal of Agriculture (1983): 509-515.

32. Spice crop, an annual report. Nepal: National Spice Crops Development Program (2007).

33. “Summary Report on Nepal Ginger Profile 2016". (2016).

34. Zoder, Lisa Sophia. "Ginger sector in Nepal". Internationale Zusammenarbelt (GIZ) GmbH (2017).

Volume 3 Issue 11 November 2019

(C) All rights are reserved by Jyoti Neupane., et al. 